\title{
PENGARUH PENGGUNAAN MEDIA FILM ANIMASIDALAM PEMBELAJARAN IPS TERPADU TERHADAP HASIL BELAJAR SISWA KELAS VIIIDI SMP KARTINI 1 BATAM TAHUN PELAJARAN 2013/2014
}

\author{
Desma Yulia, Muhammad Arifin \\ Pendidikan Sejarah, FKIP \\ Universitas Riau Kepulauan Batam \\ desmayulia48@gmail.com
}

\begin{abstract}
Abstrak
Kurang berhasilnya guru dalam menyampaikan materi mengakibatkan pembelajaran menjadi pasif dan tidak terjadi proses pembelajaran yang diharapkan. Hal tersebut terlihat dari nilai hasil belajar IPS Terpadu siswa kelas VIII SMP Kartini 1 Batam pada semester ganjil yang sebagian besar masih di bawah KKM.Penelitian ini bertujuan untuk mengetahui pengaruh penggunaan media film animasi dalam pembelajaran IPS terpadu pada materi proses perkembangan kolonialisme dan imperialisme barat terhadap hasil belajar siswa kelas VIII di SMP Kartini 1 Batam Tahun Pelajaran 2013/2014. Penelitian ini adalahpenelitian kuantitatif dengan pendekatan quasi eksperimental.Populasi dalam penelitian ini yaitu seluruh siswa kelas VIII SMP Kartini 1 Batam.Teknik pengambilan sampel menggunakan teknik sampling jenuh.Sampel dalam penelitian ini yaitu siswa kelas VIIIA dan siswa kelas VIIIB.Jenis penelitian ini dilaksanakan dengan menggunakan rancangan penelitian dua kelompok sampel yang terdiri dari kelas eksperimen dan kelas kontrol. Kelas eksperimen diberi perlakuan penggunaan media film animasi. Sedangkan pada kelas kontrol menggunakan metode ceramah. Data penelitian dikumpulkan melalui test akhir/post test setelah diberi perlakuan.Hasil penelitian dengan judul Pengaruh Penggunaan Media Film Animasi dalam Pembelajaran IPS Terpadu terhadap Hasil Belajar Siswa Kelas VIII di SMP Kartini 1 Batam Tahun Pelajaran 2013/2014 dapat dikatakan berpengaruh signifikan. Hal ini ditunjukkan dengan hasil pengujian hipotesis menerima hipotesis alternatif $\left(\mathrm{H}_{\mathrm{a}}\right)$ dan menolak hipotesis nol $\left(\mathrm{H}_{0}\right)$, artinya terdapat perubahan hasil belajar yang signifikan dari penggunaan media film animasi dalam pembelajaran IPS Terpadu.
\end{abstract}

Kata kunci: Media Film Animasi, IPS Terpadu, Hasil Belajar Siswa.

\section{PENDAHULUAN}

Belajar merupakan proses seseorang memperoleh kecakapan, keterampilan, dan sikap. Dalam proses pembelajaran terdapat beberapa komponen, dua di antaranya adalah guru dan siswa. Agar proses pembelajaran berhasil, guru harus 
aktif diantaranya dalam hal mendorong siswa untuk selalu aktif belajar dan memberikan pengalaman belajar yang memadai dengan menggunakan media-media pembelajaran yang sesuai dengan materi yang diajarkan kepada siswa. belajarsebagai suatu proses adaptasi atau penyesuaian tingkah laku yang berlangsung secara progresif (Sutikno, 2013:3).

dalam proses pembelajaran, keberhasilan pembelajaran diukur berdasarkan pada ketercapaian kompetensi yang ditetapkan sejak awal kegiatan pembelajaran sehingga semua pihak yang berpartisipasi aktif dalam proses pembelajaran (dalam hal ini siswa dan guru), telah mengetahui arah pembelajarannya. Keduabelah pihak perlu bekerjasama sedemikianrupa, saling mendukung sehingga memungkinkan tercapainya kompetensi yang ditetapkan tersebut secara meyakinkan dan untuk melaksanakan kegiatan belajar mengajar diperlukan langkah-langakah agar tujuan yang ditetapkan dapat dicapai. Hal yang harus dilakukan adalah menggunakan media yang cocok dan sesuai dengan materi yang disampaikan.

Permasalahan umum yang terjadi di sekolah pada saat proses pembelajaran adalah adanya kenyataan yang selama ini pembelajaran di sekolahberorientasi pada target penugasan materi. Menyampail _ateri dengan menggunakan media yang sebenarnya kurang sesuai dengan materi yang disampaikan. Sehingga iklim atau suasana pada saat proses belajar mengajar cendrung kaku yang membuat siswa merasa bosan, jenuh, dan malas untuk mengikuti pelajaran sehingga dapat mempengaruhi hasil belajar siswa itu sendiri. Tuntutan pendidikan yang terus meningkat mengharuskan adanya peningkatan dalam pelaksanaan proses pembelajaran. Proses pembelajaran merupakan salah satu faktor yang dapat 
mempengaruhi tinggi rendahnya prestasi siswa, karna itu peningkatannya difokuskan pada keaktifan siswa selama proses itu berlangsung.

Salah satu cara untuk mendapatkan perhatian siswa dalam proses pembelajaran yaitu dengan menggunakan media film animasi sebagai alat praga yang sesuai dengan materi yang disampaikan, perlu dibiasakan dalam proses pembelajaran. Meningkatkan minat da] iap pembelajaran akan mendorong siswa lebih terampil, proses pembelajaran yang dilaksanakan harus seimbang dengan tiori dan praktek, jika memungkinkan praktek dengan menggunakann alat praga lebih dominan dari tiori yang mereka peroleh. Dalam melaksanakan proses pembelajaran, guru harus berupaya menciptakan suatu pembelajaran yang bermakna bagi siswa. Guru merupakan seorang pendidik, pembimbing, pelatih, dan pemimpin yang dapat menciptakan suasana belajar menarik, aman, nyaman, dan kondusif pada saat di kelas maupun di luar kelas.

Berdasarkan hasil observasi dan wawancara dengan kepala sekolah dan guru, yang dilaksanakan selama tiga kali yaitu pada hari senin, tanggal 7sampai dengan10 Oktober 2013, guru tersebut mengungkapkan masalah yang sama yaitu siswa kurang mengikuti pelajaran dengan seksama yang pada akhirnya dapat mempengaruhi hasil belajar. Dari observasi dan wawancara dengan pihak sekolah dapat disimpulkan bahwa hasil pembelajaran IPS terpadu di kelas VIII masih rendah, hal ini disebabkan kurang berhasilnya guru dalam memotivasi siswa akibatnya pembelajaran menjadi pasif dan tidak terjadinya proses pembelajaran yang diharapkan. Siswa kelas VIII di SMP Kartini 1 Batam, memiliki permasalahan dimana siswa cenderung malas mengikuti belajar pelajaran IPS terpadu pada materi-materi yang sebelumnya, memang pada saat kegiatan belajar mengajar 
berlangsung guru IPS terpadu tersebut lebih cendrung menggunakan media konvensional.

\section{Media Pembelajaran}

Pembelajaran merupakan suatu kegiatan yang melibatkan sesorang dalam upaya memperoleh pengetahuan, keterampilan dan nilai-nilai positif dengan memanfaatkan berbagai sumber-sumber belajar.Pembelajaran dapat melibatkan dua pihak yaitu siswa sebagai pembelajar dan guru sebagai fasilitator. Didalam pembelajaran siswa juga dituntut untuk memperoleh hasil belajar yang memuaskan, maka dari itu diperlukan penggunaan media pembelajaran yang sesuai dengan materi pelajaran (Rian, 2009:1).

Menurut Sutikno (2013:105) mendifenisikan media pembelajaran sebagai suatu yang dapat membawa informasi dan pengetahuan dalam interaksi yang berlangsung antara pendidik dengan siswa.Selanjutnya menurut Riyana(2009:9) mengartikan media pembelajaran adalah sebagai pembawa informasi atau pesan pembelajaran yang sesuai dengan kebutuhan siswa.Sedangkan Menurut Aqip (2010:58) media pengajaran diartika sebagai segala sesuatu yang dapat digunakan untuk menyalurkan pesan (message), merangsang pikiran, perasaan, perhatian, dan kempuan siswa sehingga dapat mendorong proses belajar.

Dari beberapa pendapat para ahli diatas dapat diambil kesimpulan bahwa. Media pembelajaran merupakan segala sesuatu yang dapat menyalurkan pesan, dapat merangsang fikiran, perasaan dan kemampuan peserta didik sehingga dapat mendorong terciptanya proses belajar pada diri peserta didik guna mencapai tujuan pembelajaran. kegunaan media dalam pembelajaran adalah untuk memfasilitasi komunikasi dan belajar. Kegiatan pembelajaran tidak terlepas dari proses 
komunikasi, dimana informasi dari sumber belajar perlu di sampaikan kepada penerima (siswa), agar siswa lebih paham maka dari itu komunikasi dalam bentuk adio visual lebih diutamakan, disamping itu juga alat-alat bantu belajar sangat mempengaruhi tingkat pemahaman siswa dalam belajar.

\section{Media Film}

Seiring dengan perkembangan teknologi audio, maka lahirlah alat bantu audio visual untuk mendukung proses belajar mengajar terutama yang menekankan pada penggunaan pengalaman yang konkret. Adapun pengertian media film dari beberapa para ahli sebagai berikut:

Menurut Susilana (2009:20) media film merupakan media yang menyajikan pesan audio visual dan gerak. Sementara itu menurut Arsyad (2010:49)mengartikan film atau gambar hidup merupakan gambar-gambar dalam frame dimana frame demi frame diproyeksikan melalui lensa proyektor secara mekanis sehingga pada layar terlihat gambar itu hidup. Sedangkan menurut Trianton (2013:57) media film adalah alat penghubung yang berupa film, media masa alat komunikasi seperti radio, televise, surat kabar, majalah yang memberikan penerangan kepada orang banyak dan mempengaruhi pikiran mereka.

Dari beberapa pendapat para ahli diatas dapat diambil kesimpulan bahwa media film secara sederhana dapat didefinisikan sebagai alat bantu dalam pembelajaran yang berupa sebuah film, yang berpungsi sebagai cerita yang dituturkan kepada penonton atau peserta didik melalui rangkaian gambar bergerak dan suara. 


\section{a. Kelebihan media film}

Adapun kelebihan dari media film ini antara lain (Arsyad, 2010:49-50):

1. Film dapat melengkapi pengalaman-pengalaman dasar dari siswa ketika mereka membaca, berdiskusi, berpraktik, dan lain-lain. Film merupakan pengganti alam sekitar dan bahkan dapat menunjukan objek yang secara normal tidak dapat dilihat, seperti cara kerja jantung ketika berdenyut.

2. Film dapat menggambarkan suatu proses secara tepat yang dapat disaksikan secara berulang-ulang.

3. Disamping mendorong dan meningkatkan motivasi, film menanamkan sikap dan segi-segi efektif lainya.

4. Film yang mengandung nilai-nilai positif dapat mengundang pemikiran dan pembahasan dalam kelompok siswa.

5. Film dapat menyajikan peristiwa yang berbahaya bila dilihat secara langsung seperti lahar gunung berapi atau perilaku binatang buas.

6. Film dapat ditunjukan kepada kelompok besar atau kelompok kecil, kelompook yang heterogen, maupun perorangan.

7. Dengan kemampuan dan teknik pengambilan gambar frame demi frame, film yang dalam kecepatan normal memakan waktu satu minggu dapat ditampilkan dalam satu atau dua menit.

\section{b. Kelemahan media film}

Adapun kelemahanya dari media film antara lain (Arsyad, 2010:50):

1. Pengadaan film umumnya memerlukan biaya mahal dan waktu yang banyak 
2. Pada saat film dipertunjukan, gambar-gambar bergerak terus sehingga tidak semua siswa mampu mengikuti informasi yang ingin disampaikan melalui film tersebut.

3. Film yang tersedia tidak selalu sesuai dengan kebutuhan dan tujuan belajar yang diinginkan, kecuali film itu dirancang dengan produksi khususnya untuk kebutuhan sendiri.

\section{Hasil Belajar}

Menurut Sudjana (2004:22) hasil belajar adalah kemampuankemampuanyang dimiliki siswa setelah ia menerima pengalaman pelajaranya.Sementara itumenurut Nasution (dalam Yohanes, 2013:194) hasil belajar adalah hasil dari suatu interaksi tindak belajar dan mengajar dan biasanya ditunjukan dengan nilai tes yang diberikan guru.sedangkan hasil belajar menurut Burton (dalam Lufri, 2007:10) merupakan pola-pola perbuatan, nilai-nilai, pengertian-pengertian, sikap, apresiasi, kemampuan (ability), dan keterampilan.

Dari pendapat para ahli diatas dapat disimpulkan bahwa hasil belajar IPS terpadu adalah suatu bukti keberhasilan seseorang dalam mempelajarai meteri pelajaran IPS terpadu di sekolah yang dinyatakan dalam bentuk nilai yang diperoleh dari hasil belajar yaitu hasil tes. Biasanya nilai dari hasil belajar seseorang dalam bentuk angka, huruf atau kata-kata baik, sedang dan buruk.

Menurut Gagne (dalam Sutikno, 2013:6-7) menyebutkan, ada lima macam hasil belajar berikut ini : 
1. Keterampilan intelektual atau keterampilan prosedural yang mencakup belajar diskrimisasi, konsep, prinsip, dan pemecahan masalah yang kesemuanya diperoleh melalui materi yang disajikan oleh guru di sekolah;

2. Strategi kognitif, yaitu kamampuan untuk memecahkan masalah-masalah yang baru dengan jalan yang mengatur proses internal masing-masing individu yang memperhatikan, mengingat, dan berfikir;

3. Informasi verbal, yaitu kemampuan untuk mendiskripsi kan suatu dengan kata-kata dengan jalan yang mengatur informasi-informasi yang relevan;

4. Keterampilan motorik, yaitu kemampuan untuk melaksanakan dan mengkoordinasikan gerakan-gerakan yanga berhubungan dengan otot;

5. Sikap, yaitu seuatu kemampuan internal yang mempengaruhi tingkah laku seseorang didasari oleh emosi, kepercayaan-kepercayaan, serta faktor intelektual.

Seperti halnya dibidang lain, hasil belajar dari pembelajaran dipengaruhi oleh sumber belajar, kemampuan dasar dan sikap awal siswa, sikap dan nilai siswa terhadap mata pelajaran, motivasi siswa, kemampuan guru, proses yang diilatihkan kepada siswa, waktu dan kesempatan mempelajarai mata pelajaran. Semua hasil belajar seharusnya diukur dengan menggunakan alat ukur yang tepat. Untuk mengukur dengan benar diperlukan alat ukur yang baik dan untuk mendapatkan alat ukur demikian perlu dipelajari dan dilatihkan tentang pengembangan alat ukur hasil belajar, baik tes maupun non tes.

\section{Teori Belajar}

Teori yang digunakan dalam penelitian ini adalah teori kognitif yang dikemukan oleh David Ausubel (dalam Douglas Brown, 2007:97) berpendapat, 
bahwa pembelajaran terjadi dalam diri manusia melalui proses bermakna yang mempertalikan pristiwa atau hal baru dengan konsep kognitif atau dalil-dalil yang sudah ada. Makna bukanlah sebuah respon eksplisit, tetapi sebuah "pengalaman sadar yang dinyatakan secara jelas dan dibedakan secara tepat, yang muncul ketika isyarat-isyarat bermakna, simbol, konsep, atau gagasan memiliki kemungkinan untuk dikaitkan dengan dan dimasukan kedalam struktur kognitif tertentu seseorang pada basis yang stabil dan subtantif". Pemerolehan makna baru (pengetahuan), kemampuan mengingat, pengorganisasian pengetahuan secara psikologis sebagai sesuatu struktur yang berjenjang.

Penerapan media film animasi yang sejalan dengan teori yang dikemukakan oleh David Ausubel yaitu pembelajaran bermakna, karna media film animasi memberikan pemahaman kepada siswa berupa makna simbol-simbol atau peralatan yang menggantikan proses, kejadian, atau benda yang sebenarnya, serta menambah pengetahuan siswa dalam berpikir dan menjadikan siswa yang kreatif dalam proses pembelajaran.

\section{METODE PENELITIAN}

Berdasarkan permasalahan yang dikemukakan pada bab sebelumnya, maka jenis penelitian ini merupakan penelitian kuantitatif dengan pendekatan Quasi Experimental. Penelitian Quasi Experimental membagi objek menjadi dua kelompok, kelompok pertama yaitu kelompok eksperimen yang diberi perlakuan berupa penerapan media film animasi, dan kelompok kedua yaitu kelompok kontrol yang diberi perlakuan berbeda sebagai pembanding dengan menggunakan pembelajaran konvesional (Sugiyono,2012:114). 
Berdasarkan permasalahan yang dikemukakan pada bab sebelumnya, maka jenis penelitian ini merupakan penelitian kuantitatif dengan pendekatan Quasi Experimental. Penelitian Quasi Experimental membagi objek menjadi dua kelompok, kelompok pertama yaitu kelompok eksperimen yang diberi perlakuan berupa penerapan media film animasi, dan kelompok kedua yaitu kelompok kontrol yang diberi perlakuan berbeda sebagai pembanding dengan menggunakan pembelajaran konvesional (Sugiyono,2012:114).

Menurut Margono (1997:118) populasi adalah seluruh data yang menjadi perhatian kita dalam suatu ruang lingkup dan waktu yang ditentukan.Jadi, populasi berhubungan dengan data, bukan manusianya. Apabila setiap manusia memberikan data, maka banyaknya atau ukuran populasi akan sama dengan banyaknya manusia.

Dalam melakukan penelitian ini, populasi penelitian adalah seluruh siswa dan siswi kelas VIII SMP Kartini 1 Batam Tahun Pelajaran 2013/2014.Hal ini dari perhitungan 2 kelas Rombongan Belajar VIII A dan VIII B, rata-rata kelas terdiri dari 30 siswa.Pengambilan data berkoordinasi dengan pihak sekolah SMP Kartini 1 Batam.

Menurut Sugiyono (2012:118) sampel adalah bagian dari jumlah dan karakteristik yang dimiliki oleh populasi tersebut.Pengambilan sampel pada penelitian ini menggunakan teknik Sampling Jenuh. Sugiyono (2012:124) mengemukakan, teknik sampling jenuhadalah teknik penentuan sampel bila semua anggota populasi digunakan sebagai sampel. Hal ini dilakukan dengan memperhatikan ciri-ciri antara lain :

a. Siswa mendapatkan materi berdasarkan kurikulum yang sama

b. Siswa menjadi obyek penelitian duduk di kelas yang sama 
c. Tidak ada pembagian kelas yang unggul

Pengambilan sampel dalam penelitian ini yaitu siswa kelas VIII A SMP Kartini 1 Batam Tahun Pelajaran 2013/2014 sebagai kelas eksperimen dengan menggunakan pembelajaran media film animasi dan siswa kelas VIII B SMP Kartini 1 Batam Tahun Pelajaran 2013/2014 sebagai kelas kontrol dengan menggunakan model pembelajaran konvensional.

Instrumen yang digunakan dalam penelitian ini adalah tes hasil belajar siswa yang berbentuk soal objektif (pihan ganda) yang memiliki 4 pilihan jawaban (a, b, c, dan d). Soal yang benar diberi skor 1 dan soal yang dijawab salah diberi skor 0 , dengan jumlah soal sebanyak 40 soal namun sebelumnya instrumen tersebut diuji terlebih dahulu dengan Uji Validitas, Uji Reliabilitas, Tingkat Kesukaran, dan Daya Beda.

Teknik analisis data yang digunakan untuk membuktikan bahwa kelompok kontrol dan kelompok eksperimen berangkat dari titik tolak yang sama. Data yang digunakan dalam melakukan uji kesamaan pada siswa kelas XI IPS setelah penentuan sampel secara sampling jenuhdilakukan.Analisis ini terdiri atas uji normalitas dan uji homogenitas.

\section{PEMBAHASAN}

\section{a. Pengaruh hasil belajar siswa dengan menggunakan media film animasi dan media konvensional.}

Penelitian ini membuktikan bahwa dalam pembelajaran sejarah, jika media yang digunakan adalah media film animasi, maka hasil belajar sejarah siswa akan lebih baik jika dibandingkan dengan menggunakan media konvensional. Hal ini terlihat dari perolehan rata-rata hasil belajar materi pokok Proses Perkembangan 
Kolonialisme dan Imperiliasme barat.dengan menggunakan media media flm animasi sebesar90\% lebih baik daripada dengan menggunakan mediakonvensional56\%. Perbedaan hasil belajar ini disebabkan karena dalam penggunaan media konvenional kurang adanya hubungan timbal balik antara media dengan siswa, tampilan media film animasi lebih menarik, dan siswa lebih suka karena dalam media film animasi memuat materi yang beragam yang disertai dengan gambar, suara, dan gerakan.

Media film animasi dapat menciptakan hubungan timbal balik antara media dengan siswa, sehingga siswa akan lebih antusias dan tidak bosan dalam mengikuti pembelajaran. Hal ini dapat terjadi karena media flm animasi dirancang agar tampilannya memenuhi fungsi menginformasikan pesan dan memiliki interaktifitas kepada penggunanya.

Penggunaan media film animasi yang dapat melibatkan siswa secara aktif dalam proses pembelajaran. Dengan media film animasi yang sifatnya audiovisual kelihatan bahwa pembelajaran memiliki daya tarik tersendiri bagi siswa dan dapat menjadi pemacu atau pemotivasi siswa untuk belajar. Hal lain juga dengan media film animasi dapat mengurangi kejenuhan dalam belajar, dan juga dapat menambah daya tahan ingatan terhadap objek belajar yang dipelajari siswa. (Arsyad : 2002: 9).

\section{b. Perbedaan hasil belajar siswa dengan menggunakn media film animasi dan media konvensional.}

Nilai $t_{\text {hitung }}$ lebih besar dari nilai $t_{\text {tabel }}$ maka pengujian menerima hipotesis alternatif $\left(\mathrm{H}_{\mathrm{a}}\right)$, yaitu terdapat perubahan hasil belajar yang signifikan dari pengaruh media film animasi dalam pembelajaran IPS Terpadu pada siswa kelas VIII di 
SMP Kartini 1 Batam Tahun Pelajaran 2013/2014 dengan rata-rata nilai $\left(\mu X_{1}\right)$ sebesar 80 lebih baik dibandingkan dengan siswa yang mengikuti pembelajaran menggunakan metode ceramah dengan rata-rata nilai $\left(\mu \mathrm{X}_{2}\right)$ sebesar 68 dan menolak hipotesis nol $\left(\mathrm{H}_{0}\right)$, yaitu Tidak terdapat perubahan hasil belajar yang signifikan dari penerapan media film animasi dalam pembelajaran IPS Terpadu pada siswa kelas VIII di SMP Kartini 1 Batam Tahun Pelajaran 2013/2014,

\section{KESIMPULAN}

Berdasarkan hasil pengujian hipotesis dan pembahasan maka dapat ditarik beberapa kesimpulan dari penelitian ini, yaitu:

1. Secara keseluruhan, terdapat perubahan hasil belajar yang signifikan dari penggunaan media film animasi dalam pembelajaran IPS Terpadu pada siswa kelas VIII di SMP Kartini 1 Batam Tahun Pelajaran 2013/2014 .

2. Pada kelompok siswa yang mengikuti proses pembelajaran dengan menggunakan media film animasi memperoleh hasil belajar yang signifikan lebih tinggi dibandingkan dengan siswa yang mengikuti proses pembelajaran dengan menggunakan metode ceramah.

3. Hasil pengujian hipotesis menerima hipotesis alternatif $\left(\mathrm{H}_{\mathrm{a}}\right)$ dan menolak hipotesis nol $\left(\mathrm{H}_{0}\right)$, artinya terdapat perubahan hasil belajar yang signifikan dari pengaruh media film animasi dalam pembelajaran IPS Terpadu pada siswa kelas VIII di SMP Kartini 1 Batam Tahun Pelajaran 2013/2014..

4. Proses pembelajaran dengan menggunakan media film animasi dapat mencapai hasil belajar IPS Terpadu siswa kelas VIII yang lebih baik karena dengan menggunakan media film animasi siswa lebih 
bersemangat dalam belajar, sehingga siswa dapat menemukan pengetahuan yang diperoleh lebih mudah dan bertahan lama dalam ingatan.

\section{DAFTAR PUSTAKA}

Aqip,Zainal. 2010. Profesionalisme Guru Dalam Pembelajaran. Surabaya. Insan Cendekia.

Arikunto,Suharsimi. 2009. Dasar-dasar Evaluasi Pendidikan. Jakarta: Bumi Aksara.

2011. Prosedur Penelitian, Suatu Pendekatan Praktik. Jakarta: Rineka Cipta.

Arsyad,Azhar. 2010. Media Pembelajaran. Jakarta: PT Grafindo Persada.

Brown,Douglas. 2007. Prinsip Pemelajaran dan Pengajaran Bahasa. Jakarta. Kedutaan Besar Amerika Serikat

Hamalik ,Oemar. 1999. Kurikulum dan Pembelajaran. Jakarta: Bumi Aksara.

Lufri. 2007. Strategi Pembelajaran Biologi. Padang: UNP Press.

Margono. 1997. Metodologi Penelitian Pendidikan. Jakarta: Rineka Cipta.

Rasyid,Harun dan Mansur 2009 . Penilaian Hasil Belajar. Bandung: CV Wacana Prima.

Suciati. 2007. Belajar dan Pembelajaran 2. Jakarta: Universitas Terbuka.

Sudjana,Nana.2004. Penilaian Hasil Proses Belajar Mengajar. Bandung: PT Remaja Rosdakarya.

Sugiyono. 2012. Metode Penelitian Pendidikan. Bandung: Alpabeta.

2011. Statistika untuk Penelitian. Bandung: Alfabeta.

2010. Metode Penelitian Pendidikan. Bandung: Alpabeta.

Susilana,Rudi dan Riyana. 2009. Media Pembelajaran. Bandung: CV Wacana Prima. 
Sutikno, Sobry. 2013. Belajar dan Pembelajaran. Bandung: Holistica.

2009. Belajar dan Pembelajaran. Bandung: Prospect.

Trianton,Teguh. 2013. Film Sebagai Media Belajar. Yogyakarta: Graha Ilmu.

Nazir, Moh.2005. Metodologi Penelitian Pendidikan.Jakarta: Bumi Aksara.

Yohanes. 2013. Pendekatan, Strategi, Metode, Teknik dan Model Pembelajaran. Padang: Universitas Negeri Padang.

$\underline{h t t p: / / s t a t i s t i k a p e n d i d i k a n . c o m}$ 